\title{
Hubungan Antara Kualitas Hidup dan Olahraga dengan Kejadian Obesitas pada Mahasiswa Obesitas
}

\author{
Iqbal Ainun Najib*, Rias Gesang Kinanti, Olivia Andiana \\ Universitas Negeri Malang, Jl. Semarang No. 5 Malang, Jawa Timur, Indonesia \\ *Penulis korespondensi, Surel: iqbalainun15@gmail.com
}

Paper received: 23-7-2021; revised: 13-8-2021; accepted: 20-8-2021

\begin{abstract}
Obesity has become a global pandemic throughout the world and is declared the largest chronic disease by the WHO, the prevalence obesity in adolescents in the world is increasing continuously every year for men from 8.3 percent to 12.9 percent and for women in 8,4 to 13,4 percent in 2013. Therefore, it is necessary to make prevention efforts, one of which is by knowing the relationship between the incidence of obesity with life of quality and exercise during the pandemic in Malang State University students. This study uses a correlational quantitative methods with a causal design with the number of respondents being 20 students off the University of Malang State with inclusion and exclusion criteria. The results off this study were carried out by using the Spearman analysis test using the IBM SPSS 25.0 application between the life of quality and the obesity incidence showing a p-value of 0.000 with a corelation coefficient of 0.847 and for the quality of exercise with the obesity incidence, it showed a p-value of 0.015 with a correlation of coefficient of 0.535 which mean that there is a strong and significant relationship with a strong strength between variables. So conclusion for the research is that there is a relationship between the quality of life with the incidence of obesity and the quality of exercise with the incidence of obesity is a significant in Malang State University students.
\end{abstract}

Keywords: obesity incidence; quality of life; sport

\begin{abstract}
Abstrak
Di seluruh dunia obesitas telah menjadi pandemic dan WHO telah menyatakan sebagai penyakit kronis terbesar, Prevalensi obesitas pada remaja di seluruh dunia semakin meningkat terus menerus per tahunnya untuk pria dari 8,3 persen kemudian menjadi 12,8 persen dan untuk perempuan 8,4 menjadi 13,4 persen pada tahun 2013. Obesitas merupakan keadaan lemak berlebih yang diakibatkan ketidakseimbangan antara pemasukan dan pengeluaran energi oleh tubuh. Oleh karena itu perlunya dilakukan upaya solusi sebagai pencegahan, salah satunya dengan mencari tahu tentang hubungan antara olahraga dan kualitas hidup dengan kejadian obesitas selama pandemi pada mahasiswa obesitas Universitas Negeri Malang. Penelitian yang ini menggunakan jenis metode kuantitatif korelasional dengan desain sebab akibat dengan jumlah responden 20 mahasiswa Universitas Negeri Malang dengan syarat yaitu kriteria eksklusi dan inklusi. Hasil penelitian ini dilakukan dengan uji analisis spearman menggunakan aplikasi IBM SPSS 25.0 antara kualitas hidup dengan kejadian obesitas menghasilkan nilai p- value yaitu 0,000 dengan correlation coefficient 0,847 dan untuk kualitas olahraga dengan kejadian obesitas menghasilkan nilai $p$ - value 0,015 dengan correlation coefficient 0,535 yang artinya adanya hubungan yang kuat atau signifikan dengan kekuatan yang kuat antar variabel. Jadi kesimpulannya adalah bahwa terdapat hubungan antara kualitas hidup dengan kejadian obesitas dan kualitas olahraga dengan kejadian obesitas yang signifikan pada mahasiswa yang obesitas di Universitas Negeri Malang.
\end{abstract}

Kata kunci: kejadian obesitas; kualitas hidup; olahraga

\section{Pendahuluan}

Obesitas sendiri di penjuru dunia telah dinyatakan sebagai pandemi global dan WHO menyatakan sebagai penyakit kronis terbesar di dunia (Wulandari et al., 2016:2). Prevalensi 
obesitas pada usia remaja di seluruh dunia semakin meningkat tajam terus - menerus per tahunnya untuk pria dari 8,4 \% menjadi $12,8 \%$ dan untuk perempuan 8,4 menjadi $13,4 \%$ pada tahun 2013 (Ng et al, 2014:06). Hasil dari RISKESDAS Nasional indonesia pada tahun 2018 bahwa nilai dari prevalensi obesitas pada usia dewasa yaitu $>18$ tahun mengalami kenaikan dari tahun ke tahun nya dan lumayan signifikan di negara indonesia. Sedangkan prevalensi obesitas di usia >18 tahun yaitu kategori dewasa yakni 10,5 (4,3\%) pada tahun 2007 dan pada tahun 2014 naik sebesar 14,8 (6,4 \%) dan selanjutnya naik pada tahun 2018 menjadi 21,8 \% secara signifikan.

Sedangkan di provinsi Jawa Timur sendiri memiliki prevalensi obesitas yang cukup dan lumayan sangat tinggi di negara Indonesia, yakni pada tahun 2018 sekitar 22,36 \%, yang dimana persentase dari nilai angkanya tersebut melewati persentase prevalensi obesitas yang terjadi pada nasional (KEMENKES, 2018). Dan hasil riset dari RISKESDAS bahwa Obesitas di Kota Malang 2013 sampai 2018 memiliki prevalensi yang tinggi yaitu menjadi nomor tujuh kota tertinggi setelah kota surabaya dengan prevalensi obesitas pada dewasa di atas 15 tahun dengan prosentase 38\% dari 44\% tertinggi (KEMENKES RI, 2018). Pada studi pendahuluan yang dilaksanakan pada bulan desember 2016 di sukun kota malang menghasilkan jumlah obesitas sentral pada wanita dewasa dengan jumlah 267 orang selama tiga bulan terakhir dengan ukuran lingkar pinggang $>80 \mathrm{~cm}$ (Agustina \& Lampah, 2017). Berdasarkan uraian tersebut peneliti berpendapat bahwa kondisi mahasiswa UM juga tidak lepas dari kejadian obesitas dikarenakan UM terletak di kawasan atau lingkungan kota malang yang memiliki prevalensi obesitas tinggi di jawa timur.

Obesitas adalah keadaan lemak abnormal pada tubuh atau lemak berlebih yang dapat mengganggu kesehatan manusia (Ellulu et al., 2014:02). Obesitas sendiri disebabkan oleh beberapa faktor, yaitu aktivitas fisik, pola makan, pola tidur, psikologi, isolasi sosial pada usia anak yang termasuk dari faktor obesitas sendiri dan berpengaruh dengan kebiasaan hidup seseorang (Arisman, 2010). Salah satu faktor utama penyebab kejadian obesitas yaitu kualitas hidup dan olahraga pada seseorang. Kualitas hidup sendiri biasanya dapat digunakan sebagai alat ukur terhadap tingkat kesehatan seseorang (Larasati, 2016). Kualitas hidup sendiri dinilai dengan empat fungsi. Diantaranya fungsi fisik, fungsi emosi, fungsi sosial, fungsi sekolah atau kuliah (Khodaverdi et al, 2011). Kaitannya dengan obesitas bahwa seseorang yang mengalami atau memiliki kualitas hidup yang kurang baik maka akan mudah mengalami obesitas.

Sedangkan olahraga sendiri yaitu suatu bentuk pengeluaran energi yang lumayan besar yakni sebesar $20-50 \%$ biasanya dalam bentuk aktivitas fisik. Olahraga memiliki manfaat yang banyak dan baik bagi tubuh jika dilakukan sesuai durasi dan frekuensi yang tepat. Olahraga baik dan tepat yaitu jika dilakukan 3x per minggu selama 12 minggu karena berdampak positif yaitu meningkatkan lemak HDL dan menurunkan kadar lemak LDL (Sugiharto, 2014:79). Kurangnya aktivitas olahraga dapat menyebabkan terjadinya kelebihan energi karena minimnya energi yang dikeluarkan oleh tubuh yang selanjutnya menjadi lemak di dalam tubuh sehingga seseorang mudah mengalami obesitas akibat penumpukan lemak yang berlebih.

Berdasarkan pemikiran di atas dapat memunculkan ide atau solusi bahwa perlunya diadakan penelitian yang berjudul hubungan antara kualitas hidup dan olahraga dengan kejadian obesitas pada mahasiswa yang obesitas di Universitas negeri malang (UM). 


\section{Metode}

Metode penelitian yang digunakan yakni metode kuantitatif korelasional dengan desain sebab akibat. Teknik sampling pada penelitian ini yaitu menggunakan teknik sampling purposive dengan beberapa kriteria yaitu kriteria eksklusi dan inklusi yang berarti mahasiswa Universitas Negeri Malang didasarkan pertimbangan tertentu untuk dijadikan sampel penelitian yaitu setelah mahasiswa Universitas Negeri Malang lulus kriteria inklusi dan eksklusi. Sedangkan pelaksanaan penelitian ini dilakukan secara offline dan online dan pada penelitian ini dilaksanakan sesuai protokol kesehatan. Penelitian dilakukan pada tanggal 28 19 Januari 2021 di Laboratorium Sport Science, Fakultas Ilmu Keolahragaan Universitas Negeri Malang. Populasi pada penelitian ini yaitu 40 mahasiswa obesitas dari lima fakultas Universitas Negeri Malang.

Kriteria inklusi pada penelitian yang dilakukan yakni mahasiswa UM aktif, memiliki berat badan berlebih atau obesitas (imt $<25$ ), mengisi form informed consent sebagai bukti setuju untuk mengikuti penelitian ini, tidak sedang sakit. Sedangkan kriteria eksklusi nya yaitu sampel yang tidak memenuhi beberapa syarat penelitian, dalam keadaan sakit, dan tidak bersedia mengikuti penelitian. Pada penelitian ini menggunakan teknik pengumpulan data kuesioner berupa google form untuk mengukur tingkat kualitas hidup dan olahraga. Sementara imt dilakukan pengukuran secara online dan offline, pengukuran imt secara online menggunakan kuesioner yang berupa google form sementara pengukuran imt secara offline menggunakan alat pengukur imt yaitu tanita di laboratorium sport science. Kemudian data hasil pengukuran penelitian diuji analisis menggunakan uji spearman dengan aplikasi IBM SPSS 25.0 guna mengetahui tingkat korelasi atau hubungan antara tingkat kualitas hidup dan tingkat kualitas olahraga dengan obesitas pada mahasiswa obesitas Universitas Negeri Malang.

\section{Hasil dan Pembahasan}

Berdasarkan hasil dari penelitian sesuai variabel yaitu kualitas hidup, olahraga dan obesitas didapatkan hasil seperti di bawah ini.

Tabel 1. Kategori dan Karakteristik Obesitas pada Responden

\begin{tabular}{clcc}
\hline No & Kategori obese & Jumlah & Persentase \\
\hline 1 & Underweight & - & - \\
2 & Normal & - & - \\
3 & At Risk & - & - \\
4 & Obese I & 15 & $75 \%$ \\
5 & Obese II & 5 & $25 \%$ \\
Total & & 20 & $100 \%$ \\
\hline
\end{tabular}

Berdasarkan tabel 1 menunjukan bahwa obesitas pada kategori obese I memiliki hasil persentase tertinggi yaitu $75 \%$ dan memiliki jumlah 15 responden.

Tabel 2. Kategori dan Karakteristik Kualits Hidup pada Responden

\begin{tabular}{clcc}
\hline No & Kategori Kualitas Hidup & Jumlah & Persentase \\
\hline 1 & Kurang Baik & 17 & $85 \%$ \\
2 & Baik & 3 & $15 \%$ \\
& Total & 20 & $100 \%$ \\
\hline
\end{tabular}


Berdasarkan tabel 2 menunjukkan bahwa kualitas hidup kurang baik memiliki persentase yang besar yaitu $85 \%$ dengan jumlah 17 responden.

Tabel 3. Kategori dan Karakteristik Kualitas Olahraga pada Responden

\begin{tabular}{llcc}
\hline No & Kategori Kualitas Olahraga & Jumlah & Persentase \\
\hline 1 & Aktif & 4 & $20 \%$ \\
2 & Tidak Aktif & 16 & $80 \%$ \\
& Total & 20 & $100 \%$ \\
\hline
\end{tabular}

Berdasarkan tabel 3 menunjukkan bahwa kualitas olahraga tidak aktif memiliki presentase yang besar yaitu $80 \%$ dengan memiliki jumlah 16 responden.

Tabel 4. Hasil Analisis Hubungan Kualitas Hidup dengan Obesitas

\begin{tabular}{lccccc}
\hline $\begin{array}{l}\text { Indeks Massa } \\
\text { Tubuh }\end{array}$ & Baik & $\begin{array}{c}\text { Kualitas Hidup } \\
\text { Kurang Baik }\end{array}$ & Jumlah & \multirow{2}{*}{ P-Value } & $\begin{array}{c}\text { Correlation } \\
\text { Koefficient }\end{array}$ \\
\cline { 2 - 4 } & $\mathbf{N}$ & $\mathbf{N}$ & & & 0,847 \\
\cline { 1 - 3 } Obesitas I & 3 & 12 & 15 & & \\
Obesitas II & & 5 & 5 & & \\
Jumlah & 3 & 17 & 20 & & \\
\hline
\end{tabular}

Berdasarkan tabel 4 menunjukkan bahwa dari kategori kualitas hidup kurang baik dan obes I memiliki jumlah terbanyak dengan jumlah 12 orang. Sedangkan P-Value memiliki nilai 0,000 dan koefisien korelasi memiliki nilai 0,847 yang berarti bahwa terdapatnya hubungan yang signifikan dan kuat antara kejadian obesitas pada mahasiswa obesitas UM dengan kualitas hidup.

Tabel 5. Hasil Analisis Hubungan Kualitas Olahraga dengan Obesitas

\begin{tabular}{|c|c|c|c|c|c|}
\hline \multirow{3}{*}{$\begin{array}{c}\text { Indeks Massa } \\
\text { Tubuh }\end{array}$} & \multicolumn{2}{|c|}{ Kualitas Olahraga } & \multirow[b]{2}{*}{ Jumlah } & \multirow{2}{*}{ P-Value } & \multirow{2}{*}{$\begin{array}{l}\text { Correlation } \\
\text { Koefficient }\end{array}$} \\
\hline & Aktif & Tidak Aktif & & & \\
\hline & $\mathbf{N}$ & $\mathbf{N}$ & & \multirow{4}{*}{0.015} & \multirow{4}{*}{0,535} \\
\hline Obesitas I & 4 & 11 & 15 & & \\
\hline Obesitas II & & 5 & 5 & & \\
\hline Jumlah & 3 & 17 & 20 & & \\
\hline
\end{tabular}

Berdasarkan tabel 5 menunjukkan bahwa dari kategori kualitas olahraga tidak aktif dan obesitas I memiliki jumlah terbanyak dengan jumlah 11 orang. Sedangkan P-Value memiliki nilai 0,015 dan koefisien korelasi memiliki nilai 0,535 yang berarti bahwa terdapatnya hubungan yang signifikan dan kuat antara kejadian obesitas pada mahasiswa obesitas UM dengan kualitas olahraga.

\subsection{Hubungan Kualitas Hidup dengan Kejadian Obesitas}

Didapatkan hasil bahwa responden pada penelitian ini yang mempunyai tingkat kualitas hidup yang kurang baik sangat berdampak pada meningkatnya berat badan atau imt pada mahasiswa obesitas Universitas Negeri Malang. Hal tersebut dibuktikan bahwa dari 20 
responden terdapat 17 responden yang kurang baik tingkat kualitas hidupnya dengan memiliki berat badan yang obesitas, dan hanya ada 3 responden dalam klasifikasi obesitas yang mempunyai kualitas hidup baik. Dari hasil penelitian tersebut menunjukkan bahwa tingkat kenaikan imt atau status obesitas seseorang berbanding lurus dengan tingkat penurunan kualitas hidup.

Semakin besar kemungkinan terjadinya obesitas pada seseorang maka semakin besar juga tingkat penurunan kualitas hidup. Hasil ini searah dengan penelitian Park (2017) menyatakan bahwa orang yang obesitas memiliki lebih rendah kualitas hidup dibandingkan dengan orang yang normal. Hal ini juga searah dengan penelitian yang dilaksanakan oleh (Kolotkin \& Anderson, 2017) pada penelitian ini mengemukakan bahwa obesitas dikaitkan dengan kualitas hidup yang lebih rendah secara signifikan di semua populasi. Dan sepakat juga dengan Khodija et al (2013) yang menghasilkan bahwa pada remaja adanya hubungan antara obesitas dengan kualitas hidup yang lumayan signifikan.

Obesitas sendiri yakni terjadinya antara energi yang keluar dengan yang masuk pada tubuh tidak seimbang, kemudian ditandai dalam jaringan adiposa adanya lemak yang menumpuk (Onis et al, 2010). Dalam kaitannya dengan kualitas hidup, dampak obesitas bagi kualitas hidup dapat menyebabkan penurunan tingkat kualitas hidup bagi seseorang yang mengakibatkan penurunan pada aspek fisik dan aspek psikososial (sosial, dan emosional, dan juga lingkungan). Selain itu, dampak obesitas pada kualitas hidup juga dapat menyebabkan penurunan dalam kesehatan seseorang akibat penurunan kualitas hidup yang disebabkan karena berat badan yang berlebih atau obesitas. Menurut Nurmalina \& Valley (2011). Faktor faktor utama terjadinya obesitas yaitu kurang nya dari keseimbangan energi, gaya hidup pasif, emosional, dan lingkungan.

Obesitas sendiri memiliki dampak yang buruk pada psikologis serta kesehatan fisik seseorang terutama pada anak- anak dan remaja. Di bidang sosial dan atletik anak-anak obesitas merasa mereka kurang kompeten bila dibandingkan dengan anak non obesitas, serta kurang menarik dan berharga (Hanifratiwi et al., 2013). Sebuah studi komprehensif menunjukkan adanya pengaruh negatif terhadap HRQoL pada populasi usia anak yang memiliki status berat badan meningkat atau obesitas, ditandai IMT nya di atas normal dengan adanya penurunan tingkat kualitas hidup (Khairy et al., 2016).

\subsection{Hubungan Olahraga dengan Kejadian Obesitas}

Pada penelitian ini juga menghasilkan bahwa yang termasuk kedalam kategori obesitas sangat berdampak pada kualitas olahraga nya dimana responden obesitas memiliki kualitas olahraga yang tidak aktif pada mahasiswa Universitas Negeri Malang. Hal tersebut dibuktikan bahwa dari 20 responden yang merupakan mahasiswa yang berasal dari beberapa fakultas yakni 5 fakultas di UM. dan terdapat 16 responden yang memiliki tingkat kualitas olahraga yang tidak aktif dengan berat badan yang tergolong dalam klasifikasi obesitas, dan hanya ada 4 responden yang masuk dalam klasifikasi obesitas dan mempunyai kualitas olahraga yang aktif. Dari penelitian tersebut menghasilkan penurunan kualitas olahraga seseorang berbanding lurus dengan tingkat kenaikan imt atau status obesitas seseorang.

Hasil ini searah dengan penelitian dari Zulkarnain \& Alvina, (2020) yang menyatakan bahwa antara kebiasaan olahraga dengan munculnya obesitas abdominal memiliki hubungan yang amat bermakna. Hasil ini juga searah dengan penelitian dari Syam (2017) Hasil penelitian 
nya menunjukan hal bahwa antara aktivitas fisik dengan kejadian obesitas terdapatkan hubungan yang kuat. Hasil ini juga sepakat dengan penelitian dari Manja et.al (2020) dengan hasil bahwa di antara kebiasaan olahraga dengan obesitas ada hubungan yang signifikan pada mahasiswa Fakultas IKM UM Pontianak.

Obesitas sendiri biasanya ditandai dengan adanya penumpukan lemak dalam jaringan adiposa yang merupakan dampak dari energi yang masuk dengan yang di keluar kan tidak seimbang, (Onis et al, 2010). Dampak obesitas juga menyebabkan penurunan tingkat olahraga pada seseorang, dikarenakan behavior sedentary atau gaya hidup pasif yang membuat aktivitas terbatas hanya diam di dalam rumah saja. Sedentary behavior menyebabkan kurangnya aktivitas olahraga atau rendahnya aktivitas olahraga pada seseorang, semakin aktivitas fisik seorang lakukan rendah maka akan sedikit pula dari energi seseorang yang dikeluarkan atau energy expenditure. Energi tubuh yang dikeluarkan relatif rendah dan tingkat masukan makanan yang besar atau energi intake pada seseorang dengan sedikitnya kualitas tidur dapat menjadikan berat badan naik dan obesitas (Firdaningrum, 2020).

Aji Nur Salin (2014) menyatakan bahwa terlalu banyak nya lemak dalam tubuh dapat berakibat nya obesitas ini diakibatkannya aktivitas fisik seseorang yang kurang hingga mengakibatkan hilangnya massa otot tubuh dan berkurang yang mempunyai fungsi sebagai mesin yang membakar lemak pada tubuh melemah,. Teraturnya seseorang beraktivitas olahraga dan terus meningkatkannya dan mengurangi penggunaan berbagai alat - alat digital dan elektronik sebagai hiburan. Aktivitas fisik yang sangat sedikit dapat menyebabkan massa otot tubuh semakin sedikit pula, sehingga mudah banget akan mengalami lemak berlebih atau menumpuk (Rusyadi, 2017).

\section{Simpulan}

(1) Adanya hubungan antara kualitas hidup dengan kejadian obesitas pada mahasiswa obesitas Universitas Negeri Malang yang signifikan. (2) Adanya hubungan antara olahraga dengan kejadian obesitas pada mahasiswa obesitas Universitas Negeri Malang yang signifikan. Pada penelitian perlunya dilakukan penelitian lebih lanjut dengan sampel usia dewasa dengan jumlah sampel yang lebih banyak. Dapat juga untuk penelitian selanjutnya dibuat perbandingan antara kelompok pria dan kelompok perempuan sebagai subjek penelitian. Untuk penelitian selanjutnya disarankan menambahkan instrumen penelitian untuk mengukur kualitas hidup dan kualitas olahraga pada sampel penelitian. Disarankan juga untuk para mahasiswa yang obesitas menerapkan kualitas hidup yang baik dan tetap aktif menjalankan olahraga secara teratur agar kondisi bugar dan sehat.

\section{Daftar Rujukan}

Arisman, M. (2010). Buku Ajar Ilmu Gizi. Egc.

Ellulu., Mohammed., Abed, Y., Rahmat, A., Ranneh, Y., \& Faisal, A. (2014). Epidemiology of obesity in developing countries : Challenges and preventif. 1-6.

Firdaningrum, N. E. (2020). Hubungan antara durasi tidur dengan asupan makan, aktifitas fisik dan kejadian obesitas pada mahasiswa program studi pendidikan dokter Uin Maulana Malik Ibrahim Malang. In Skripsi.

Kementerian Kesehatan. (2020). Peraturan Menteri Kesehatan tentang Pedoman Pembatasan Sosial Berskala Besar Dalam Rangka Percepatan Penanganan Corona Virus Disease 2019. Parallax, 9-19.

Kementerian Kesehatan RI Badan Penelitian dan Pengembangan. (2018). Hasil Utama Riset Kesehatan Dasar. Kementrian Kesehatan Republik Indonesia. 
Khodaverdi, F., Alhaani, F., Kazemnejad, A., \& Khodaverdi, F. (2011). The Relationship Between Obesity and Quality of Life in School Children. Public Health Journal, 40(2), 96-101.

Khodija, Lukman, D., \& Munigar, M. (2013). Obesitas dengan kualitas hidup remaja. Jurnal Health Quality, 3(2), 69-140.

Kolotkin, R. L., \& Anderson, J. R. (2017). A systematic review of reviews: exploring the relationship between obesity, weight loss and health-related quality of life. Clinical Obesity Published, 7, 273-289.

Larasati. (2016). Kualitas Hidup Pasien Diabetes Melitus Tipe II di RS Abdul Moeloek Provinsi Lampung. In Kedokteran Universitas Lampung.

Manja, P., Marlenywati., \& Mardjan. (2020). Hubungan Antara Konsumsi Kafein, Screen Time, Lama Tidur, Kebiasaan Olahraga dengan Obesitas pada Mahasiswa Fakultas Ilmu Kesehatan Universitas Muhammadiyah Pontianak. Jurna Mahasiswa Dan Kesehatan, 7(1), 1-9.

Ng, M., Fleming, T., Robinson, M., Thomson, B., Graetz, N., Margono, C., Mullany, E. C., Biryukov, S., Abbafati, C., Abera, S. F., Abraham, J. P., Abu-Rmeileh, N. M. E., Achoki, T., Albuhairan, F. S., Alemu, Z. A., Alfonso, R., Ali, M. K., Ali, R., Guzman, N. A., ... Gakidou, E. (2014). Global, regional, and national prevalence of overweight and obesity in children and adults during 1980-2013: A systematic analysis for the Global Burden of Disease Study 2013. The Lancet. https://doi.org/10.1016/S0140-6736(14)60460-8

Nurmalina, R., \& Valley, B. (2011). Pencegahan dan Managemen Obesitas. PT Elex Media Komputido.

Onis M, \& Bloonser M, B. E. (2010). Global prevalence and trends of overweight and obesity among preschool children. Am J Clin Nutr, 92:, 1257-1264.

Park, S. (2017). Pathways linking obesity to health-related quality of life. Springer International Publishing Switzerland, 12, 2209-2218.

Rusyadi, S. (2017). Pola makan dan tingkat aktifitas fisik mahasiswa dengan berat badan berlebih di Universitas Negeri Yogyakarta. SKripsi Program Study Pendidikan Teknik Boga Fakultas Teknik Universitas Negeri Yogyakarta, 79.

Sugiharto. (2014). fisiologi olahraga teori dan aplikasi pembinaan olahraga. Malang. Universitas Negeri Malang.

Syam, Y. (2017). Hubungan Aktifitas Fisik dengan Kejadian Obesitas pada Anak Usia Sekolah Di SD Negeri Mangkura 1 Makasar. Skripsi Program Study Ilmu Keperawatan Fakultas Keperawatan Universitas Hasanuddin Makassar, 31-39.

Zulkarnain, A. \& Alvina, A. (2020). Hubungan kebiasaan berolahraga dan merokok dengan obesitas abdominal pada karyawan usia produktif. Jurnal Biomedika Dan Kesehatan, 3(1), 2127.https://doi.org/10.18051/jbiomedkes.2020.v3.21-27. 